DOI: $10.2478 / \mathrm{v} 10122-011-0013-6$

\title{
THE DUAL DISTAL DEMONSTRATIVE IN MODERN STANDARD ARABIC: BETWEEN NORMS AND NON-CANONICITY
}

\author{
MARCIN MiCHALSKI
}

\begin{abstract}
Marcin Michalski. The Dual Distal Demonstrative in Modern Standard Arabic: Between Norms and Non-Canonicity. Lingua Posnaniensis, vol. LIII (2)/2011. The Poznań Society for the Advancement of the Arts and Sciences. PL ISSN 0079-4740, ISBN 978-83-7654-173-0, pp. 61-73.

The system of the demonstrative pronouns in Classical Arabic (CA), on which that of Modern Standard Arabic (MSA) is based, is distance-oriented and has been described as a two-term (proximal-distal) or three-term (proximal-medial-distal) system. A characteristic feature of the subsystem of the distal demonstratives in CA was that it had a suffix indicating the gender and number of the addressee(s). Within the subsystem of distal demonstratives, the dual form has not been described in a unanimous way: authors do not agree as to its form, some give more than one, others do not mention the issue, while according to some descriptions this form does not exist at all. In MSA texts, the function of the dual distal demonstrative is, however, sometimes carried out by a form which according to CA rules should be used when a singular object is pointed to and two persons are being addressed. This means that some users of MSA have reinterpreted the CA indicator of a dual addressee, -kuma $\bar{a}$, as the indicator of the duality of the object pointed to.
\end{abstract}

Marcin Michalski, Institute of Linguistics, Adam Mickiewicz University, al. Niepodległości 4, PL - 61-874 Poznań.

\section{INTRODUCTION}

The grammar of Modern Standard Arabic (MSA), although rooted in - and to many idealistic Arabs identical with - that of Classical Arabic (CA) described by medieval Arabic grammarians, has undergone substantial modifications. Some contemporary, especially Western, Arabists try to do justice to new phenomena in this language in a descriptive way, like for instance EL-AyouBI et al. (2003) and BADAWI et al. (2004), while others, notably Arab philologists take a normative stance and either do not pay attention to innovations or dismiss them as errors. It is therefore important to record new tendencies in MSA and describe them, taking into account descriptions of related elements in the classical or classicizing normative literature. It is easy to observe that the usage presented or recommended in normative works frequently does not tally with what is employed in real texts, that the real language has, in some respects, severed itself from the canonical rules and developed new ones. It seems that this is often the case when canonical grammatical rules are relatively complex, like for instance those governing the syntax of numerals, or when a particular 
form is rarely used. Arguably, the latter concerns the dual form of the distal demonstrative, which, apart from its classical forms, has ones which, to my knowledge, have not yet been identified in scholarly literature. The new forms might obviously be considered an error and therefore not taken into account by linguists and philologists, however, they are too widespread to be neglected. In some writers' texts they have supplanted the canonical forms. In this paper it will be shown how the issue of the dual distal demonstrative has been treated in (mostly normative) classicizing Arabic grammars and by (mostly descriptive) Western Arabists. Then, examples of the non-canonical dual distal demonstrative from MSA texts will be adduced and the form will be discussed.

\section{CLASSICIZING ARABIC GRAMMARS}

There is little agreement in twentieth-century classicizing Arabic grammars as to what the system of the demonstratives looks like. According to HASAN (n.d.), an authoritative and acknowledged grammar of Arabic, the demonstratives are divided with respect to (i) the number and gender of the object pointed to and (ii) its distance. All demonstratives can be reduced to basic, simple forms (with no affixes) inflecting for number and gender. These are presented in Table 1 (all tabular representations in this paper are mine).

Ta b le 1. Basic demonstratives according to HaSAN (n.d.)

\begin{tabular}{|c|c|c|c|c|}
\hline \multicolumn{2}{|c|}{ Singular } & \multicolumn{2}{|c|}{ Dual } & Plural \\
\hline Masculine & Feminine & Masculine & Feminine & Masculine/Feminine \\
\hline$\underline{d a}$ & $\begin{array}{l}\underline{d} \bar{l}, \underline{d i h}, \underline{d i h i}, \underline{d i h} \bar{\imath}, \\
\underline{d} \bar{a} t, \\
t \bar{l}, t \bar{a}, t i h, t i h i, t i h \bar{l}^{1}\end{array}$ & $\begin{array}{l}\text { NOM } \underline{d} \bar{a} n i \\
(\underline{d} \bar{a} n n i) \\
\text { OBL } \underline{d} \text { dayni } \\
\text { (dayanni) }\end{array}$ & $\begin{array}{l}\text { NOM tāni } \\
\text { (tānni) } \\
\text { OBL tayni } \\
\text { (tayanni) }\end{array}$ & $u l \bar{a}, u l \bar{a}{ }^{\prime} i$ \\
\hline
\end{tabular}

As regards the dual forms, which are of interest to us here, two things must be observed. First, they inflect for case, unlike the singular and plural pronouns. Second, the dual demonstratives have synonymous variants with geminated $n$ (HASAN n.d.: 323 ). ${ }^{2}$

The second division is with respect to distance. ${ }^{3}$ HasAn distinguishes three distances: proximity (al-qurb), mediality (at-tawassut), and remoteness (al-bu'd) (n.d: 322 and 324). The evaluation of the distance, as Hasan writes, depends on "the general custom" (al- urf $a \check{s}-\check{s}^{\prime}{ }^{\prime} i^{\prime}$ ) prevailing between the speaker and his or her interlocutor(s) (p. 322, fn. 1). It is not said who or what is the point of reference when determining the distance but it may be supposed that it is the speaker (some grammars state this explicitly). The Arabic three-term system as presented by Hasan belongs to the "distance oriented" systems, i.e. those in which the basic semantic distinctions of the pronouns are ones of relative distance from the speaker (cf. Anderson \& KeEnAn 1985: 282). ${ }^{4}$ We will not be concerned here with the question if this

${ }^{1}$ Other Arab grammarians enumerate less forms, for instance AL-HĀšIMİ gives only $t \bar{a}, t \bar{l}, t i h i, \underline{d} \bar{l}, \underline{d i h i}$ for the feminine (n.d.: 94) and AL-ĠALĀYīnI only $\underline{d i h}$ and $\operatorname{tih}$ (2002: 95).

${ }^{2}$ HASAN describes them as forms "with $y$ vocalized with $a$ " (tataharrak al-yā'bi-l-fatha) and adduces explicitly on p. 344 , fn. 2 .

${ }^{3}$ According to another opinion, represented by the classical grammarian IBN ĞINNī (d. 1002), the demonstra-

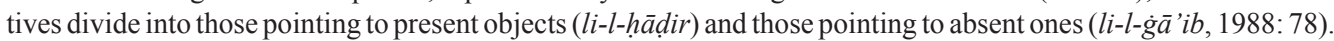

${ }^{4}$ Another type is "person oriented", in which the middle term "marks objects as being in some sense close to or 
three-distance division was really observed in CA or is observed in MSA (for the latter see EL-AyouBi et al. 2003: 69-78).

For pointing to close objects the simple pronouns listed in Table 1 are used, which can be preceded by $h \bar{a}$ - (HASAN n.d.: 327), resulting in commonly used proximal demonstra-

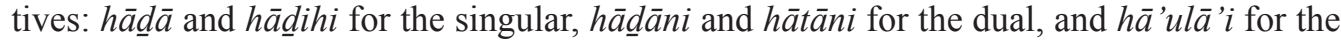
plural.

Medial objects, i.e. those situated somewhere between close and remote, are pointed to by means of some proximal pronouns, namely: $\underline{d} \bar{a}, t \bar{l}, t \bar{a}, \underline{d} \bar{\imath}$, and $u l \bar{a}$ ' $i$, expanded by the suffix indicating mediality (al-harf ad-dāll 'alā at-tawassut), which is the $-k$-called $k \bar{a} f$ al-hitāa al-harfiyya 'suffixal $k$ of address' or harf hitāāb 'suffix of address' (HASAN n.d.: 324-325, discussed in more detail in Section 4).

Finally, the distal demonstratives, i.e. those which point to remote objects, are formed by means of two affixes: the so-called làm al-bu'd 'the $l$ of remoteness', i.e. the affix -l-, which must be followed by the kāf al-hițāb al-harfiyya (HASAN n.d.: 325-326). Not every basic demonstrative accepts the lām al-bu' $d$. It is accepted by the singular masculine demonstrative $\underline{d} \bar{a}$ (from which $\underline{d} \bar{a} l i k a$ results), the feminine $t \bar{l}, t \bar{a}, \underline{d} \bar{l}$ (Hasan adduces only one result: $t i l k a$ ) and the plural ula (which results in $u l \bar{l} l i k a$ ), but not by the dual demonstratives (pp. 326-327). ${ }^{5}$ Consequently, the three-distance system presented by Hasan is defective: there is no dual distal demonstrative. This system can be presented as follows (suffix $-k a$ in the medial form indicates one male addressee):

Ta b le 2. Dual demonstratives according to Hasan (n.d.)

\begin{tabular}{|c|c|c|c|c|c|}
\hline \multicolumn{2}{|c|}{ Proximal } & \multicolumn{2}{|c|}{ Medial } & \multicolumn{2}{|c|}{ Distal } \\
\hline Masculine & Feminine & Masculine & Feminine & Masculine & Feminine \\
\hline $\begin{array}{l}\text { NOM }(h \bar{a}) \underline{d} \bar{a} n i \\
((h \bar{a}) \underline{d} \bar{a} n n i) \\
\mathrm{OBL}(h \bar{a}) \underline{d a y n i} \\
((h \bar{a}) \underline{d} \text { dayanni })\end{array}$ & $\begin{array}{l}\text { NOM }(h \bar{a}) \text { tānni } \\
((h \bar{a}) \text { tānni }) \\
\text { OBL }(h \bar{a}) \text { tayni } \\
((h \bar{a}) \text { tayanni })\end{array}$ & 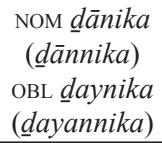 & $\begin{array}{l}\text { NOM tānika } \\
(\text { tānnika }) \\
\text { oBL taynika } \\
(\text { tayannika })\end{array}$ & & \\
\hline
\end{tabular}

The systems of the demonstrative pronouns presented by other classicizing Arab authors differ from Hasan's and tend to be less detailed. In what follows, I will concentrate on the problem of the dual forms and, then, the kā $f$ al-hit $\underline{\text { ta }} b$.

Below, Table 3 shows the demonstratives in the dual according to AL-HĀšı̀ì (n.d.: 97-98):

Ta b le 3. Dual demonstratives according to al-HĀšı̀ī (n.d.)

\begin{tabular}{|c|c|c|c|c|c|}
\hline \multicolumn{2}{|c|}{ Proximal } & \multicolumn{2}{c|}{ Medial } & \multicolumn{2}{c|}{ Distal } \\
\hline Masculine & Feminine & Masculine & Feminine & Masculine & Feminine \\
\hline NOM $(h \bar{a}) \underline{d} \bar{a} n i$ & NOM $(h \bar{a})$ tāni & NOM $\underline{\text { dănika }}$ & NOM tānika & NOM $\underline{\text { dănnika }}$ & NOM tānnika \\
OBL $(h \bar{a}) \underline{d} a y n i$ & OBL $(h \bar{a})$ tayni & OBL $\underline{\text { daynika }}$ & OBL taynika & OBL ? & OBL ? \\
\hline
\end{tabular}

Al-Hāšimī's dual distal forms in the nominative are identical with Hasan's $n$-geminated variants of the medial forms. Their oblique forms are vocalized in al-Hāšimī’s book as

idendifiable by the $A d r$ (addressee - M.M.)". It is found, for instance, in Japanese (ANDERSON \& KEENAN 1985: 282).

${ }^{5}$ Hasan does not explain why this is so nor if and how one could express the meaning of a dual distal demonstrative in some other way. Further on he remarks that since the dual has no distal forms (and since the feminine distal forms are identical to the medial ones), some grammarians argue that there is only a two-term division into proximal and distal, without the medial (the medial forms merging with the distal ones) (HASAN n.d.: 331). 
dayyinika and tay.nnika, which seem to be misprints since in the feminine $y$ is unvocalized and the masculine has ungeminated $n$, while earlier on the author had written explicitly that the distal forms have geminated $n$ (as the - $l$ - indicating remoteness never occurs there, p. 94 and 98). ${ }^{6}$ Al-Hāšimī's forms should most probably be read dayinnika/tayinnika (or, less probably, daynnika/taynnika ${ }^{7}$ ). Such a three-distance system is also presented in AD-DAHDĀH (1989) and BuHADŪD (1987), with the difference that ad-Dahdāḥ's distal forms in the oblique cases are clearly dayinnika and tayinnika (AD-DAḤDĀH 1989: 96), while according

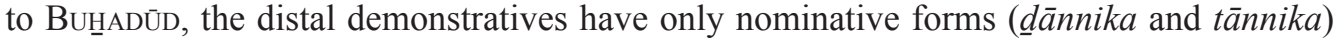
(BüADŪD 1987: 37 and 39), which, moreover, are characterized as "rarely used" (nādirat al-isti 'māl, BüHADŪD 1987: 39).

The two-term system of the demonstrative pronouns, mentioned by HASAN (see fn. 5), is presented, for instance, in a university textbook by ȘAQR (n.d.). According to this author, "the $k \bar{a} f$ indicates that the object is remote", which means that the mere presence of the affix - $k$ - makes a demonstrative distal. An example of it is $\underline{d} \bar{a} k a$ (medial in Hasan's system), in which $-l$ - can be added before $-k$ - to result in (apparently synonymous) $\underline{d} \bar{a} l i k a$ (S. AQR n.d.: 119). However, Saqr fails to indicate the dual forms with $-k$-, from which expanded synonymous forms with $-l$ - could (or not) be formed. The system of the demonstratives in the dual according to Saqr can be represented in the following way:

Ta ble 4. Dual demonstratives according to ȘAQR (n.d.)

\begin{tabular}{|c|c|c|c|}
\hline \multicolumn{2}{|c|}{ Proximal } & \multicolumn{2}{c|}{ Distal } \\
\hline Masculine & Feminine & Masculine & Feminine \\
\hline NOM $(h \bar{a}) \underline{d} \bar{a} n i$ & NOM $(h \bar{a}) t \bar{a} n i$ & \multirow{2}{*}{ not indicated } & not indicated \\
OBL $(h \bar{a}) \underline{d}$ aynni & OBL $(h \bar{a})$ tayni & \multicolumn{2}{|c}{} \\
\hline
\end{tabular}

From what has been shown so far it can be seen that the dual distal demonstrative pronoun is particular in many respects. Various authors present various systems, some of which are defective: some authors state explicitly that a dual form with an - $l$-indicating distality does not exist (Hasan). In some systems, the dual distal demonstrative has two variants: with $-n$ - and -nn-, which are described as equivalent (Hasan) or as forming an opposition medialdistal (al-Hāšimī). It should also be noted that the dual distal demonstrative is the only distal demonstrative that inflects for case. Perhaps it is this complex situation that accounts for the fact that many Arab authors of shorter and simplified descriptions, especially school and academic textbooks, like Șaqr, do not mention the problem at all. Examples of such fragmentary descriptions include Kitāb an-naḥw (2003-2004), addressed to non-Arabic speakers, in which the issue of the dual distal demonstrative is not raised (2003-2004: 27-28). Similarly, in the chapter on demonstratives in the grammar by FAYYĀD, only proximal demonstratives are listed (1995: 31-32). The matter is treated likewise by AL-ḦAmĀDī et al. (1994: 15) and AL-ĞĀRIM \& AMīN (n.d.a: 141). If the reader of the older but popular compendium by ALĠALĀYīni follows the author in that the distal form must be composed of $-l-$ and $-k$ - (2002: 96), he or she might erroneously deduce that the dual distal form is $\underline{d} \overline{a n l i k a}$ (which does not

${ }^{6}$ It is sometimes claimed that the geminated $n$ may be the result of an assimilation of the distal $l$ to $n$ (da ānnika from * $\left.{ }^{d} \bar{a} n l i k a\right)$, e.g. Hasselbach (2007: 9, fn. 43).

${ }^{7}$ I consider the forms with gemination, daynnika and taynnika, less probable as they are relatively hard to pronounce and not in agreement with Arabic phonotactic rules, according to which three non-vowels consecutively, here -ynn-, are rather avoided. Such forms are, however, given by several Western scholars (see Section 3). 
exist). Unfortunately, the author, adducing only singular forms $\underline{d} \bar{a} l i k a$ and tilka, does not put the reader right. Also in the grammar by 'ABD AL-LAṬ̄F et al. no clear division with respect to distance is made and no full list of demonstratives is given (1997: 27-28).

\section{WESTERN DESCRIPTIONS}

Generally, in Western descriptions of CA, the two-distance system is presented. WRIGHT speaks of $(h \bar{a}) \underline{d} \bar{a}$ as of indicating an object that is near to the speaker (1974: 265), while compound forms with $-k$ - indicate remote objects. ${ }^{8}$ The forms of the demonstratives in the dual according to WrighT (pp. 266-267) can be presented as follows:

Ta ble 5. Dual demonstratives according to Wright (1974)

\begin{tabular}{|c|c|c|c|}
\hline \multicolumn{2}{|c|}{ Proximal } & \multicolumn{2}{|c|}{ Distal } \\
\hline Masculine & Feminine & Masculine & Feminine \\
\hline NOM $(h \bar{a}) \underline{d} \bar{a} n i$ & NOM $(h \bar{a}) t \bar{a} n i$ & $\begin{array}{l}\mathrm{NOM} \underline{d} \bar{a} n i k a \\
(\underline{d} \bar{a} n n i k a)\end{array}$ & $\begin{array}{c}\text { NOM tānika } \\
(\text { tāannika) }\end{array}$ \\
\hline $\mathrm{OBL}(h \bar{a}) \underline{d} a y n i$ & OBL $(h \bar{a})$ tayni & $\begin{array}{c}\text { OBL daynika } \\
\text { (daynnika) }\end{array}$ & $\begin{array}{c}\text { OBL taynika } \\
(\text { taynnika) }\end{array}$ \\
\hline
\end{tabular}

The same system is presented by GRANDE (2001: 377-378), who adds that forms other

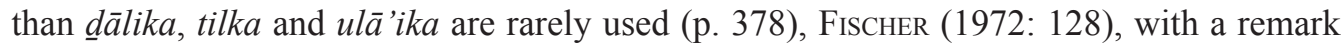
that in the singular forms with -lika are preferred, and DANECKI (1994: 335-337), who speaks of simple and compound distal demonstratives (in the dual without and with gemination, respectively).

Many other Western descriptions of MSA, or Arabic in general, present such a twodistance system but tend to make the forms simpler. In general, the forms of the dual distal

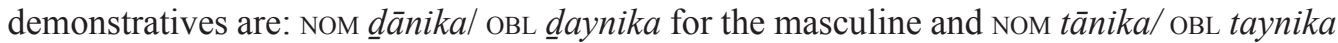
for the feminine, with no variant with gemination. ${ }^{9}$ Such a system is presented by CORRIENTE (2002: 111), Holes (2004: 185), Haywood \& Nahmad (1965: 81), Abu-Chacra (2007: 99) and El-Ayoubi et al. (2003: 69). By contrast, BucKLey indicates only the forms with gemi-

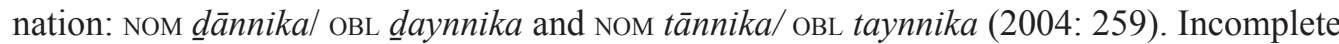
descriptions can be found as well: Kouloughli (1994: 120) and BADAwI et al. (2004: 47) indicate only the nominative forms ( $\underline{d} \bar{a} n i k a$ and tānika), which can misleadingly suggest to the reader that these words do not inflect. RYDING says that "the demonstrative of distance" is "rarely used in the dual" and does not indicate these forms (2005: 316). The issue of dual distal forms is not raised at all in Schultz (2008: 97).

To sum up, those who consult the books by Arab authors, especially school and academic grammars, about the dual form of the distal demonstrative will find contradictory, chaotic or no information there. In general, Western sources can be said to be more coherent in treating this issue.

${ }^{8}$ WRIGHT remarks, however, that according to some (Arab) grammarians there is a difference of meaning between the distal demonstratives referring to the nearer or more remote of two distant objects (1974: 265). This is also observed by GRANDE (2001: 378) and El-AyouBI et al. The latter add that language usage provides no evidence for a differentiation between medial and distal deixis (2003: 69).

${ }^{9}$ These are also the forms given by Arabic native speakers I have consulted on this point. 


\section{THE $k \bar{a} f a l-\underline{h} i t a \bar{a} b$ (THE ' $k \bar{a} f$ OF THE ADDRESS')}

It has already been said that the form of the $k \bar{a} f a l-\underline{h} i t \bar{a} b$, i.e. the suffix of the address, reflects the gender and number of the person addressed. Thus, when pointing to a singular masculine object, one says $\underline{d} \bar{a} k a$ when addressing one male, $\underline{d} \bar{a} k i$ when addressing one female, $\underline{d} \bar{a} k u m \bar{a}$ when addressing two persons, $\underline{d} \bar{a} k u m$ when addressing more than two males and $\underline{d} \bar{a} k u n n a$ when addressing more than two females. This usage is called by Hasan attașarruf al-kāmil ('full inflection'), is said to be "the best known and elevated of all usages" (ašhar al-luḡàt wa-asmāhā, HASAN n.d.: 324, fn. 2) and recommended as "enhancing the clarity of expression and preventing ambiguity" (ziyādat al-ị̂ạh wa-man "al-labs). Apart from 'full inflection', there is also at-tașarruf an-nāqiș, 'defective inflection', which consists in using forms ending in $-k a$ when the addressee(s) is/are male and forms ending in $-k i$ when the addressee(s) is/are female, irrespective of their number. According to Hasan, this kind of inflection is inferior to the former (wa-huwa fi darağatihi aqall min al-awwal). Finally, 'absolute non-inflection' ( 'adam at-tașarruf mutlaqan) means that for all kinds of addressees the uninflected $-k a$ is employed (p. 324, fn. 2).

Let us now consider some pertinent examples from the Qur'ān. The 'full inflection' is exemplified in 1, where the addressee is masculine plural, and in 2, where the addressee is dual (Adam and his wife):

$\begin{array}{lll}\text { dâalikum-u } & \text { llāhu } & \text { rabbu-kum } \\ \text { that } & \text { Allah } & \text { Lord-your.PL }\end{array}$

'That is Allah, your Lord' [6:102]

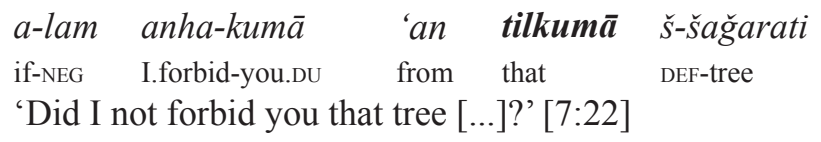

In 3 , however, the - $k a$ remains uninflected, although the addressee ("ye who believe") is masculine plural:

\begin{tabular}{|c|c|c|c|c|}
\hline $\begin{array}{l}\text { dâlika } \\
\text { that }\end{array}$ & $\begin{array}{l}\text { tahfifun } \\
\text { easing }\end{array}$ & $\begin{array}{l}\min \\
\text { from }\end{array}$ & $\begin{array}{l}\text { rabbi-kum } \\
\text { Lord-your.PL }\end{array}$ & $\begin{array}{l}\text { wa-rahmatun } \\
\text { and-mercy }\end{array}$ \\
\hline
\end{tabular}

'This is a concession and a Mercy from your Lord' [2:178]

Full inflection in 1 and 2 and its absence in 3 may be explained by the fact that full inflection was not obligatory in the Quranic language. Let us now consider how the issue of inflecting the $k \bar{a} f a l-\underline{h} i t \bar{a} b$ is presented in grammars. As it has already been observed, Hasan sees in the choice between inflecting and non-inflecting a choice between superior and inferior usage but he treats all of them as acceptable. Similarly, AD-DAḦĀH says that "purest Arabic" (al-afșah) is to inflect the suffix (1989: 96), which suggests that not to inflect it is Arabic too. 'ABD AL-LAṬ̄F et al. write that the suffix may inflect (wa-qad tatașarraf) or not, in which case it ends in -a (wa-qad la tatașarraf wa-talzam al-fath), however, they do not say if this is left to free choice (1997: 29). By contrast, 'ĪD states explicitly that a demonstrative with the kâf al-hițāb "must agree with the addressee" (wağaba an yurā ' $\bar{a}[\ldots]$ ma huwa muwağğah ilayhi) (1982: 163). AL-HĀšımī simply informs the reader that the kāf al-hinitāb in- 
flects (n.d.: 98). Also the way how AL-ĠALĀYĪNĪ (2002: 97) and ȘAQR (n.d.: 118) write about the use of inflected $k \bar{a} f$ - "you say" (taqūlu) - suggests that it is obligatory to use full inflection. Similarly, the rule given by AL-ĞĀRIM \& AMĪN stating that "the kāf agrees (tuțābiq) with the addressee in all the mentioned [categories, i.e. gender and number]" (n.d.b: 180), suggests that inflection is obligatory. It can thus be said that Arab authors either recommend at-tașarruf al-kāmil or present it as obligatory.

Western authors have a different view on this usage, including in CA, probably because their approach is much more descriptive. To begin with, RECKENDORF observes that the singular form $-k a$ is used even when a number of people is addressed (1921: 289). Similarly, in WRIGHT we read that the form ending in - $k a$ may be "- and in fact usually is employed, whatever be the sex and number of the persons spoken to" (1974: 266). FISCHER says that inflected forms are sometimes found in pre-Classical Arabic (before the end of the 8th cent.) and adds: "Die Beziehung auf die angeredete Person ist jedoch verblaßt" (1972: 128). GRANDE mentions that the $-k a$ is inflected "in old texts" ( $v$ staryh tekstah) (2001:378), without, however, saying if it is always the case or not. As for authors describing specifically MSA, BADAwI et al. consider such inflection "largely Qur'anic practice", which is "still followed in highly formal style" (2004: 47). EL-AyouBI et al. speak of "Reminiszens der Sprache des Korans" sporadically employed in MSA. According to these scholars, authors who use it associate with it a certain emotionalization of the utterance ("eine gewisse Emotionalisierung der Aussage", 2003: 71). It can be seen that, generally, Western Arabists agree that this usage is not or never has been obligatory.

\section{THE DUAL DISTAL DEMONSTRATIVES IN MSA TEXTS}

In what follows, examples illustrating the use of the dual forms of the distal demonstrative discussed above in real texts written in MSA are presented..$^{10}$ First, the use of the mas-

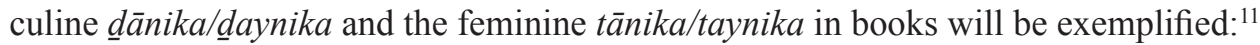

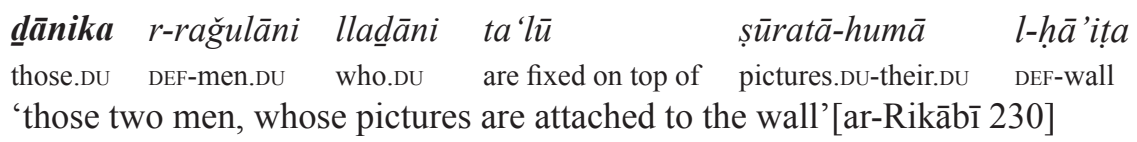

lam yadri mā yaf'alu amāma daynika l-kā'inayni
neg he.knew what he.does in the face of those.Du DEF-beings.Du
'He did not know what to do in the face of those two beings'[Nāğ'1 143]

$\begin{array}{llllll}\text { wa-mā } & \text { humā } & \text { tānika } & \text { l-muškilatāni } & \text { l-asāsiyyatāni } & \text { llatāni }[\ldots] ? \\ \text { and what } & \text { they.DU } & \text { those.DU } & \text { DEF-problems.DU } & \text { DEF-basic.DU } & \text { which.DU }\end{array}$

'And what are those two basic problems which [...]?' [Nu'ayma 160]

10 All examples in this paper have been gathered in the course of chance reading in MSA literature and searching in Google Book Search and websites of selected newspapers. The following web domains of important Arabic newspapers have been searched: international.daralhayat.com (al-Hayāt), aawsat.com (aš-Šarq al-Awsat), ahram.org.eg (al-Ahrām), thawra.alwehda.gov.sy (at-Tawra), and alrai.com (ar-Ra’y).

11 Where no sign of gemination ( $\check{s} a d d a$ ) was given in print, I preferred reading ungeminated forms to geminated ones ( $\underline{d} \bar{a} n i k a$ to $\underline{d} \bar{a} n n i k a$ etc). This was the case in all the examples adduced here. 


$$
\begin{aligned}
& \text { ilā l-istimtā'i bi-murāqabati taynika l-fahidayni } \\
& \text { to DEF-delight with-observation those.Du DEF-thighs.DU } \\
& \text { 'to delight in observing those two thighs' [Nāğ̄i 134] }
\end{aligned}
$$

Examples for $\underline{d} \bar{a} n i k a$ used in press:

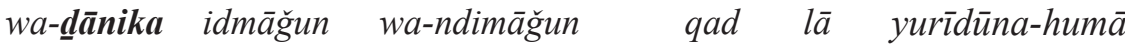

$$
\begin{aligned}
& \text { and those.Du assimilating and-getting assimilated maybe neg they want-them.Du }
\end{aligned}
$$

$$
\begin{array}{lll}
\text { hilāla } & \text { daynika } & \text { l-yawmayni } \\
\text { during } & \text { those.Du } & \text { DEF-days.Du } \\
\text { 'during those two days' [aš-Šarq al-Awsat }{ }^{\mathrm{A}} \text { ] }
\end{array}
$$

No example for tānika has been encountered in journalistic texts. There are, however, occurrences of its oblique form, for instance:

$$
\begin{aligned}
& \text { wa-fi ayyin min taynika l-marhalatayni fa-l-'aqlu fì hāatati l-gìyābi } \\
& \text { and in either of those.DU DEF-stages.DU CONJ-DEF- in state DEF- } \\
& \text { reason absence }
\end{aligned}
$$

'and in either of these two stages the reason is in the state of absence' [at- Tawra $^{\mathrm{A}}$ ]

All the forms illustrated in 4-10 seem to be employed quite rarely, partly because two infrequently occurring situations must meet. First, the object pointed to must be dual, second, it must be treated as remote in some way (by contrast, dual proximal demonstratives are used very often). In my opinion, however, the low frequency of the use of these forms should also be explained in another way, by pointing to the following phenomenon: the demonstratives $\underline{d} \bar{a} n i k a$ and tānika (and their oblique forms) are replaced by non-canonical forms, viz.

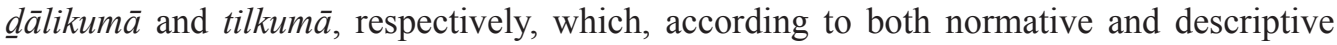
accounts, are distal demonstratives for singular masculine and feminine, respectively, used when addressing two persons. In what follows, examples of such usage of $\underline{\text { dalikuma }}$ are given, starting with those encountered in books:

$$
\begin{array}{llll}
\text { fa-ğhadī an tahyaw } & \text { dālikumā } & \text { l-yawmayni hayātan } & \text { radiyyatan } \\
\text { so strive.PL so that you.PL live those.Du } & \text { DEF-days.Du life } & \text { satisfied } \\
\text { 'so strive to spend those two days with satisfaction' [al-Kawākibī 161] }
\end{array}
$$

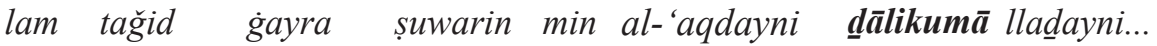
NEG she.found other.than copies.PL of DEF-contracts.DU those.DU which.DU 'she found nothing but copies of the two contracts, those which...' [Salām 55]

$\begin{array}{llll}\text { tamannat law lamasat } & \text { dälikumā } & \text { n-nahdayni } \\ \text { n-nahdayni if she.touched those.Du } & \text { DEF-breasts.Du } \\ \text { 'she wished to touch those two breasts' [Mahmmūd 65] }\end{array}$


Examples from journalistic texts:

$$
\text { țiwāla dāalikumā l-yawmayni lam tanfağir amām-ī } \begin{aligned}
& \text { sayyāratun mufa- } \\
& \text { hahahatun }
\end{aligned}
$$

during those.DU DEF-days.DU NEG exploded in front of-me car bomb 'during those two days no car bomb exploded in front of me' [aš-Šarq alAwsat $\left.{ }^{\mathrm{B}}\right]$

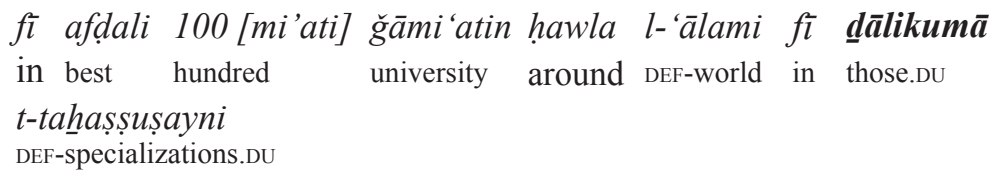

'among the 100 best universities in the world in those two specializations' [aš-Šarq al-Awsat ${ }^{\mathrm{C}}$ ]

$\begin{array}{llcl}\text { dâalikumāa } & \text { lays } \bar{a} & \text { mitâlayni } & \text { ma 'zülayni } \\ \text { those.Du } & \text { are not.Du } & \text { examples.Du } & \text { isolated.Du } \\ \text { 'those [two] } & \text { are not isolated examples' [ar-Ra'y] }\end{array}$

Examples of tilkumā from books:

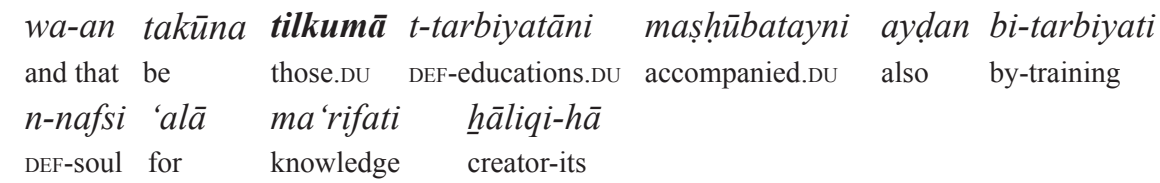

'and that those two educations be accompanied by teaching the soul the knowledge of its creator' [al-Kawākibī 139]

$\begin{array}{llll}\text { lākin ayyu šay'in kāna qad aṣbaha } & \text { aqalla faza'an min tilkumāa } \\ \text { but any thing has become } & \text { less frightening than those.Du } \\ \text { l-'aynayni } & & & \\ \text { DEF-eyes.Du } & & & \end{array}$

'but anything has now become less frightening than those two eyes' [as-Sa'dāwī 41] zalla yuhaddițu așdiqā'a-hu [...] 'an tilkumā l-ibtisāmatayni r-rā'íatayni he kept talking friends.PL-his about those.DU DEF-smiles.DU DEF-wonderful.DU 'he kept talking to his friends about those two wonderful smiles' [Šuqayr 34]
luġatun țālitatun harağat min raḥimi tilkuma $\overline{\boldsymbol{a}}$ l-luğatayni language third emerged from womb those.DU DEF-languages.DU 'a third language that has emerged from the womb of those two' [Nașrallāh 167]

Finally, examples of tilkumā encountered in journalistic language are given:

$$
\begin{aligned}
& \text { ilā l-aḥwāši wa-l-mabān̄i } \quad f i ̀ \text { tilkumā l-ǧihatayni } \\
& \text { to DEF-courtyards.PL and-DEF-buildings.PL in those.DU DEF-areas.DU } \\
& \text { 'to the courtyards and buildings in those two areas' [al-Hayāt }{ }^{\mathrm{B}} \text { ] }
\end{aligned}
$$


(22)

$\begin{array}{lll}\text { tilkumā } & \text { nașịhatāni } & \text { li-š-šabābi } \\ \text { those.DU } & \text { pieces.Du of advice } & \text { for-DEF-youth }\end{array}$

'Those are two pieces of advice for the youth' [at-Tawra ${ }^{\mathrm{B}}$ ]

\begin{tabular}{|c|c|c|c|c|}
\hline $\begin{array}{l}\text { tilkumā } \\
\text { those.DU }\end{array}$ & $\begin{array}{l}\text { humā } \\
\text { they.DU }\end{array}$ & $\begin{array}{l}\text { ğanāhāa } \\
\text { wings.Du }\end{array}$ & $\begin{array}{l}\text { taqāfati } \\
\text { culture }\end{array}$ & $\begin{array}{l}\text { t-tanmiya } \\
\text { DEF-development }\end{array}$ \\
\hline
\end{tabular}

In fact, all the demonstratives ending in -kuma $\bar{a}$ that I have encountered in MSA texts, both books and journalistic texts, are dual distal demonstratives used instead of $\underline{d} \bar{a} n i k a /$ daynika or tānika/taynika, and not demonstratives with reference to a dual addressee (except for quotations from the Qur'ān). Since the authors who practise this usage are renowned writers (suffice it to mention 'Abd ar-Raḥman al-Kawākibī, Mīhnā'îl Nu'ayma, or Nawāl as-Sa ${ }^{6}$ dāwī) or journalists writing for most important Arabic newspapers, these occurrences are evidently no mistakes. As for chronology, the two earliest occurrences in my (admittedly limited) corpus come from AL-KAWĀKIBİ's book written in 1901-1902. This means that this non-canonical usage is at least a century old and despite this, to my knowledge, not yet described. Perhaps this state of affairs might be explained in terms of grammarians and linguists considering this usage an error, this, however, does not seem convincing. On the contrary, some did note down the very occurrence of it but failed to recognize in it a new phenomenon. Thus, my example 18, taken from a novel by Nawāl as-Sa'dāwī, was adduced by EL-Ayoubi et al. (2003: 71) as an example of a demonstrative with inflected -ka, which, according to them, is used by some MSA authors in order to render the utterance more emotional. This means that the role of the suffix -kuma in tilkuma (used in tilkuma $\bar{l}$ l-'aynayni 'those two eyes'/'jene beide Augen') would be conveying emotionalization. However, in such a case tilkumā could only refer to a plural (impersonal) object, while 'aynayni is dual. For this sentence, such an emotionalizing (i.e. quasi-dual-addressee) demonstrative pointing to a dual object (al- 'aynayni 'eyes') would have to be taynikumāa (genitive of tānikumāa). In reality, -kumā indicates here nothing but the duality of the eyes.

Let us now try to describe this new usage of $\underline{d} \bar{a} l i k u m \bar{a} / t i l k u m a \bar{a}$ structurally. To this purpose, the canonical usage of tilkuma exemplified in CA tilkuma $\bar{s}$ ššăgarati 'that tree (said to a dual addressee)' in 2, will be compared with the non-canonical usage of tilkumā exemplified in MSA tilkumā l- 'aynayni 'those two eyes' in 18. The comparison, made with respect to what meanings are conveyed by these two demonstratives and which particular segments of theirs - stem or suffix - are responsible for conveying a particular meaning, is shown in Table 6 .

Ta b l e 6. Comparison of canonical and non-canonical usage of tilkumā

\begin{tabular}{|c|c|c|c|}
\hline & & \multirow[b]{2}{*}{ Canonical usage } & \multirow{3}{*}{$\begin{array}{c}\text { Non-canonical usage } \\
\text { tilkumā l-'aynayni }\end{array}$} \\
\hline & & & \\
\hline & & tilkumā š-šağarati & \\
\hline \multirow{3}{*}{ 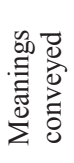 } & Number of the object pointed to & singular (til-) & dual $(-k u m \bar{a})$ \\
\hline & Gender of the object pointed to & feminine (til-) & feminine (til-) \\
\hline & Number of the addressee & dual $(-k u m \bar{a})$ & - \\
\hline
\end{tabular}

Treating the issue diachronically, one can speak of two changes that the classical tilkum $\bar{a}$ has undergone to acquire its non-canonical function: 
1. The suffix -kumā has lost its function of, or ceased to be understood as, indicating the number of the addressee and been reinterpreted as the indicator of the number of the object pointed to (duality of the addressee $>$ duality of the object pointed to). The reference to the addressee has disappeared.

2. The stem of the demonstrative, til- (and $\underline{d} \bar{a} l i$ - in $\underline{d} \bar{a} l i k u m a \bar{a}$ ), has lost its function of indicating both number and gender of the object pointed to and has been reinterpreted as the indicator of its gender only.

It should also be remarked that such non-canonical dual distal demonstratives which end in -kuma $\bar{a}$ indicating the number of the object pointed to constitute formal irregularities within the system. All the remaining distal demonstratives, dālika, tilka and ula 'ika, end in $-k a$ and the number of the object they point to is indicated by their stems ( $\left.\underline{d} \bar{a} l i-, t i l-, u l \bar{a}{ }^{\prime} i-\right)$, not the $k$-suffixes.

\section{CONCLUSION}

The fact that MSA authors use demonstrative pronouns that are in conflict with CA and MSA norms generates several questions. First, do these authors use them consciously and intentionally choose not to respect the normative rules and to express themselves differently, possibly in order to overcome the problem of unclear or even contradictory rules and to make things easier? Or is the non-canonical usage of demonstratives ending in -kuma rather an unintended error that has become very widespread? To this first question another is linked: what is the status of $\underline{d} \bar{a} n i k a$ vs. $\underline{\text { dalikuma }}$ in the language awareness of the speakers of MSA? Educated MSA speakers I consulted on this point know the canonical dannika/ tānika and maintain that they use them when necessary, although they admit that they are rare. As for the non-canonical $\underline{d} \bar{a}$ likumāaltilkumāa, the attitudes towards them range from knowing that they are in use but not considering them good Arabic to unawareness of such usage, which, however, the discovery having been made, sometimes turns into approval thereof. Another question is how widespread this usage is and whether it has gained the upper hand over the canonical one. Furthermore, it could be worth investigating if there is any geographical variation in its use (the texts making up my corpus come only from the east of

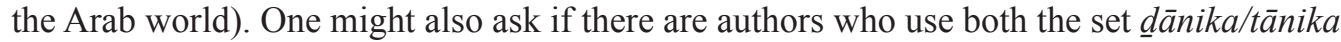
and the set $\underline{d} \bar{a}$ likumā/tilkumā in the function of the dual distal demonstratives but differentiate somehow between them, rather than there being authors observing classical rules and others practising the non-canonical usage. Another question is how this innovation should be taught to students of MSA: whether it should be mentioned in Arabic textbooks, passed over, or simply stigmatized as incorrect. 


\section{LIST OF EXCERPTED SOURCES}

\section{Books (the date of edition is not necessarily the date of the first edition):}

al-Kawākib̄i

'Abd ar-Raḥmān al-Kawākibī (Syria, 1849-1902), Tabā'i' al-istibdād wa-mașāri' alisti 'bād, 2006, Bayrūt: Dār an-Nafā'is.

Mahmūd:

Mayy 'Abd al-Karīm Maḥmūd (no data), Lu'bat al-būh (translation of Confidence pour confidence by Paule Constant), 2007, Bayrūt: Al-Mu'assasa al-'Arabiyya li-d-Dirāsāt wa-nNašr.

Nāğì:

Ğamāl Nāğ̄i (Jordan, b. 1954), Laylat ar-rīš, 2004, Bayrūt: Al-Mu'assasa al-‘Arabiyya li-dDirāsāt wa-n-Našr.

Nașrallāh: $\quad$ Ibrāhīm Nașrallāh (Jordan-Palestine, b. 1954), Aqall min 'aduww, aktar min șadīq: as-sīra aț-tā 'ira, 2006, Bayrūt: Al-Mu'assasa al-‘Arabiyya li-d-Dirāsāt wa-n-Našr.

Nu'ayma: Mīhnāî̀l Nu'ayma (Lebanon, 1889-1988), Yā bna Ādam! Hiwār bayna rağulayn, 1988, Bayrūt: Mu'assasat Nawfal.

Qur'ān: The Meaning of the Holy Qur'ān, 1999, Translated by 'Abdullāh Yūsuf 'Alī, Beltsville, Maryland: amana publications.

ar-Rikābī: Abd al-Hֵāliq ar-Rikābī (Iraq, b. 1946), Ațās al-kalām, 2009, Bayrūt: Al-Mu'assasa al'Arabiyya li-d-Dirāsāt wa-n-Našr.

as-Sa'dāwī: Nawāl as-Sa'dāwī (Egypt, b. 1931), Imra'a 'inda nuqtat aṣ-șifr, 2006, Al-Qāhira, Maktabat Madbūlī.

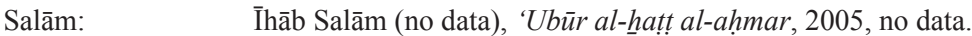

Šuqayr: Maḥmūd S Šuqayr (Palestine, b. 1941), Șūrat Š̄ākīrā: qiṣaș qașīra, 2003, Bayrūt: Al-Mu’assasa al-‘Arabiyya li-d-Dirāsāt wa-n-Našr.

Press (all websites retrieved on 29.10.11):

al-Ahrām:

al-Hayāt ${ }^{\mathrm{A}}$ :

al-Hayāt ${ }^{\mathrm{B}}$ :

ar-Ra'y:

24.11.08, http://www.ahram.org.eg/Archive/2008/11/24/OPIN5.HTM

16.03.08, http://international.daralhayat.com/archivearticle/197833

11.07.11, http://international.daralhayat.com/ksaarticle/286859

no date, http://www.alrai.com/pages.php?opinion_id=1009

aš-Šarq al-Awsaț : 08.03 .11 , http://www.aawsat.com/details.asp?section=17\&issueno=11788\&article $=611476$

aš-Šarq al-Awsaț ${ }^{\mathrm{B}}$ : 14.07.04, http://www.aawsat.com/leader.asp? section=3\&article $=244780 \&$ issueno $=9360$

aš-Šarq al-Awsaṭ ${ }^{\mathrm{c}}$ : 08.10.11, http://aawsat.com/leader.asp? section=3\&article=643994\&issueno=12002

at-Tawra ${ }^{\mathrm{A}}$ : $\quad$ 23.06.11, http://thawra.alwehda.gov.sy/_archive.asp?FileName=59885822420110622220416

at-Tawra ${ }^{B}$ : $\quad 23.04 .08$, http://thawra.alwehda.gov.sy/_archive.asp?FileName $=66301627420080422215745$

\section{REFERENCES}

'ABd AL-LațīF Muḥammad Hamāsa, 'Umar Aḥmad Muḥtār, ZAhrān Muṣțafā an-Naḥhās. 1997. An-naḥw alasāsī. Al-Qāhira: Dār al-Fikr al-'Arabī.

Abu-Chacra Faruk. 2007. Arabic: An Essential Grammar. London-New York: Routledge.

Anderson Stephen R., Keenan Edward L. 1985. “Deixis.” In: Shopen 1985: 259-308.

Badawi Elsaid, Carter M.G., Gully Adrian. 2004. Modern Written Arabic. A Comprehensive Grammar. London-New York: Routledge.

Buckley Ron. 2004. Modern Literary Arabic. A Reference Grammar. Beirut: Librarie du Liban.

BūHAdūD 'Alī Bahā' ad-Dīn. 1987. Al-madḥal an-naḥwī: taṭbìq wa-tadrīb fì an-naḥw al- 'arabī. Bayrūt: AlMu’assasa al-Ğāmi'iyya li-d-Dirāsāt wa-n-Našr wa-t-Tawzī'.

Corriente Federico. 2002. Gramática árabe. Barcelona: Herder.

AD-DAḤĀḤ Anțwān. 1989. Mu'ğam qawā'id al-luğa al-'arabiyya fì ğadāwil wa-lawhāt. Bayrūt: Maktabat Lubnān.

DANECKI Janusz. 1994. Gramatyka języka arabskiego. Warszawa: Wydawnictwo Akademickie Dialog. 
EL-Ayoubi Hashem, Fischer Wolfdietrich, LANGer Michael. 2003. Syntax der arabischen Schriftsprache der Gegenwart. Band I, 2. Teil. Die konnektiven Wortarten des Nomens. Wiesbaden: Reichert Verlag.

FAYYĀp̣ Sulaymān. 1995. An-naḥw al- 'aṣrī: dalīl mubassaṭ li-qawā 'id al-luġa al-'arabiyya. Al-Qāhira: Markaz al-Ahrām li-t-Tarğama wa-n-Našr.

FisCHER Wolfdietrich. 1972. Grammatik des klassischen Arabisch. Wiesbaden: Otto Harrassowitz.

AL-ĠALĀYīnī Mușțafā. 2002. Ğāmi ' ad-durūs al 'arabiyya. Mawsū 'a min țalātat ağzā'. Șaydā-Bayrūt: Al-Maktaba al-'Așriyya.

AL-Ğ̄̄erm 'Alī, Amīn Mușțafā. (n.d.)a. An-naḥw al-wāẹih fì qawā'id al-lugia al-'arabiyya li-l-marḥala alibtidā'iyya, vol. 2. Al-Qāhira: Dār al-Ma'ārif.

AL-Ğ̄̄erm 'Alī, Amīn Mușțafā. (n.d.)b. An-naḥw al-wādịh fì qawā'id al-lugia al-'arabiyya li-l-madāris atțānawiyya, vol. 2. Al-Qāhira: Dār al-Ma‘ārif.

GRANDE B.M. 2001. Kurs arabskoj grammatiki v sravnitel'no-istoričeskom osveščenii. Moskva: Izdatel'skaja firma "Vostočnaja Literatura" RAN.

AL-ḤAmĀDī Yūsuf, Aš-ŠINNĀWī Muḥammad Muḥammad, 'AṬ̄ Muḥammad Šafīq. 1994. Al-qawā 'id al-asāsiyya fì an-naḥw wa-ș-șarf li-talāmīẹ al-marhala aț-țānawiyya wa-mā fì mustawāhā. Al-Qāhira: Al-Hay'a al'Āmma li-Šu'ūn al-Mațābi' al-Amīriyya.

HaSAn Abbas. (n.d.). An-naḥw al-wāfi: ma 'a rabtihi bi-l-asālīb ar-rafí 'a wa-l-hayāt al-lugiawiyya al-mutağaddida, vol. I. Al-Qāhira: Dār al-Ma‘ārif.

AL-Hāšı̀ì Aḥmad. (n.d). Al-qawā'id al-asāsiyya li-l-luġa al- 'arabiyya: ḥasb manhağ "Matn al-Alfiyya” li-Ibn Mālik wa-hulāṣat aš-šurrāh li-Ibn Hišām wa-Ibn 'Aqūl wa-al-Ašmūnī. Bayrūt: Dār al-Kutub al-'Ilmiyya.

Hasselbach Rebecca. 2007. "Demonstratives in Semitic." Journal of the American Oriental Society 127(1), $1-27$.

Haywood J.A., Nahmad H.M. 1965. A New Arabic Grammar of the Written Language. London: Lund Humphries.

HoLes Clive. 2004. Modern Arabic. Structures, Functions and Varieties. Washington, D.C.: Georgetown University Press.

IBN ĞınNī. 1988. Al-lam ‘ fĩ al- 'arabiyya. Ed. Samīḥ Abū Mug̉in̄. ‘Ammān: Dār Mağdālāwī li-n-Našr.

'ĪD Muḥammad. 1982. An-nahww al-muṣaffā. Al-Qāhira: Maktabat aš-Šabāb.

Kitāb an-naḥw 2003-2004. = Kitāb an-naḥw wa-ș-ṣarf wa-l-imlā' li-l-mustawayayn at-țālit wa-r-rābi'. Dimašq: Wizārat at-Tarbiya - Ma'had Ta 'līm al-Ağānib al-Lug̉a al-'Arabiyya.

Kouloughti D.E. 1994. Grammaire de l'arabe d'aujourdhui. [s.1.]: Pocket.

ReCKendorf H. 1921. Arabische Syntax. Heidelberg: Carl Winter.

Ryding Karen C. 2005. A Reference Grammar of Modern Standard Arabic. Cambridge: Cambridge University Press.

ȘAQR Aḥmad. (n.d.). Dirāsāt fì ba ‘ḍ abwāb an-naḥw. Al-Qāhira: Ğāmi'at al-Qāhira - Kulliyyat Dār al-'Ulūm Dār at-Taqāfa al-'Arabiyya.

Schultz Eckehard. 2008. A Student Grammar of Modern Standard Arabic. Cambridge: Cambridge University Press.

Shopen Timothy (ed.). 1985. Language Typology and Syntactic Description, vol. III, Grammatical Categories and the Lexicon. Cambridge: Cambridge University Press.

Wright W. 1974. A Grammar of the Arabic Language, vol. 1. Beirut: Librairie du Liban. 